\title{
Activity of marine sediment bacterial communities exposed to 4-bromophenol, a polychaete secondary metabolite
}

\author{
Charles R. Lovell*, Charles C. Steward**, Tina Phillips \\ Department of Biological Sciences and Belle W. Baruch Institute of Marine Science and Coastal Research, \\ University of South Carolina, Columbia, South Carolina 29208, USA
}

\begin{abstract}
Many marine infaunal hemichordates and polychaetes produce volatile halogenated secondary metabolites, including several brominated aromatic compounds. These compounds have been suggested to have antimicrobial activity. However, the impact of added bromometabolites on microbial activities in undisturbed sediments has not been assessed. This study examines the effects of a common bromometabolite, 4-bromophenol, on substrate respiration and assimilation by undisturbed sediment bacterial communities. Intact sediment cores were collected from a site inhabited by the bromophenol producing capitellid polychaete Notomastus lobatus and from a similar site having no bromometabolite producing infauna. These cores were injected with a radiolabeled substrate (acetate or glucose) and varying levels of 4-bromophenol, then incubated at in situ temperature. Rates of respiration and assimilation of the substrates at levels of 4 -bromophenol ranging from ambient to $10 \mathrm{\mu g} \mathrm{g}^{-1}$ (dry weight) sediment were determined. No significant inhibition of respiration or assimilation of either substrate was observed in samples from either location, even at 4-bromophenol levels $100 \times$ the ambient concentration in wormbed sediments. These data show that this naturally occurring bromoaromatic compound has no significant effect on community activity of sediment bacteria.
\end{abstract}

KEY WORDS: Bromophenols · Bromometabolites · Marine sediment - Bacterial activity

\section{INTRODUCTION}

A variety of marine infaunal hemichordates and polychaetes produce 1 or more volatile brominated secondary metabolites, including but not limited to bromophenols, bromopyrroles, and bromobenzyl alcohols (Woodin et al. 1987, Woodin 1991). The biochemistry of bromometabolite production by these animals (Chen et al. 1991, Yoon et al. 1994, Fielman \& Targett 1995), the range of compounds produced (Woodin et al. 1987. Woodin 1991, Steward et al. 1995), and their distributions and concentrations in marine sediments (King 1986, Woodin 1991, Steward et al. 1992, Steward \& Lovell 1997, D. Lincoln, K. Fielman, R. Marinelli \& S.

\footnotetext{
-Address for correspondence: Department of Biological Sciences, University of South Carolina, Columbia, South Carolina 29208, USA. E-mail: lovell@biol.sc.edu

-Present address: Reckitt \& Colman Inc., One Philips Parkway, PO Box 425, Montvale, New Jersey 07645-0425, USA

Woodin unpubl. data) have received considerable study. Bromometabolites are found at significant levels in the animals' tissues, in sediments lining the animals burrows, and in surrounding bulk sediments (King 1986, Lincoln et al. unpubl.). The specific ecological role(s) of these compounds and their potential toxic effects on sediment macro- and microbiota have been subjects of active inquiry.

Bromometabolites have been hypothesized to function as microbiocides, inhibiting bacterial growth in burrows of the infauna producing them (Ashworth \& Cormier 1967, Sheikh \& Djerassi 1975, King 1986, Goerke \& Weber 1991). An antipredator function for these compounds has also been proposed (Prezant et al. 1981, Woodin et al. 1987, Pawlik 1993). In addition, some bromometabolites clearly inhibit recruitment of juveniles of bromometabolite non-producing infaunal species (Woodin 1991, Woodin et al. 1993), thus functioning as negative recruitment cues. The effects of bromometabolites on microbial community activity are 
of particular interest since the sediment microbiota are responsible for significant turnover of these compounds (Steward \& Lovell 1997) and may reduce their impact(s) on epibenthic and benthic macrofauna.

Sediment slurry experiments have shown inhibition of aerobic glucose respiration (King 1986) and of nitrification (Giray \& King 1997) by bromophenols. However, several other studies indicate little or no antimicrobial activity of biogenic bromophenols against sediment microflora. Steward et al. (1992) found no significant effects of ambient biogenic bromophenols produced by the capitellid polychaete Notomastus lobatus (4-bromophenol, 2,4-dibromophenol, and 2,4,6-tribromophenol) on distributions or activities of bacteria or microalgae in wormbed sediments. Microbial communities in burrows of 2 bromometabolite producing marine polychaetes (Capitella capitata and $N$. lobatus) and 2 bromometabolite producing marine hemichordates (Saccoglossus kowalevskyi and Stereobalanus canadensis) have been examined using direct microscopic counting (Alongi 1985, Jensen et al. 1992) and phospholipid fatty acid profiling (Steward et al. 1996) procedures. These studies also revealed no broad-spectrum microbiocidal activity of these compounds. Microbial biomass in bromometabolite containing sediments and burrows is comparable to that in similar but uncontaminated sediments and burrows (Steward et al. 1992, 1996, Steward \& Lovell 1997). Microbial communities residing in bromometabolite containing sediments and burrows are also quite diverse, comparable to those in corresponding uncontaminated sediments and burrows (Steward et al. 1996). However, the potential of bromometabolites to inhibit microbial community activity when present at the high levels found in burrow linings (> $800 \mathrm{ng} \mathrm{g}^{-1}$ sediment in burrows of $N$. lobatus, Lincoln et al. unpubl. data) has not been completely resolved.

This study examines the effects of 4-bromophenol, the most abundant Notomastus lobatus product in wormbed sediments, on sediment bacterial activities. Bacterially mediated turnover (Steward \& Lovell 1997) and other loss factors apparently limit biogenic 4 -bromophenol accumulation in these sediments to around $100 \mathrm{ng} \mathrm{g}^{-1}$ sediment. We tested a broad range of concentrations ranging from ambient bulk sediment levels to levels greatly exceeding those in burrow linings for inhibitory effectiveness. A major emphasis of these experiments was to avoid unnecessary disruption of the sediments that might contribute to artifactual stimulation of microbial activities (Findlay et al. 1985, 1990) or disruption of protective biofilm or microcolonial formations (e.g. Costerton et al. 1987). High-level nutrient additions were also avoided. The impact of 4-bromophenol on metabolism of 2 different carbon substrates by sediment microbial communities was evaluated.

\section{MATERIALS AND METHODS}

Study sites. The North Inlet estuary $\left(33^{\circ} 20^{\prime} \mathrm{N}\right.$, $79^{\circ} 10^{\prime} \mathrm{W}$ ) is a small (3200 ha), Spartina alterniflora dominated marsh system near Georgetown, South Carolina, USA. Dame et al. (1986) and Pinckney \& Zingmark (1993) have provided detailed descriptions of this system. The capitellid polychaete Notomastus lobatus is abundant in intertidal sediments at several locations in North Inlet and its burrows can be recognized in the field by their characteristic crescentshaped openings, spiral path in the sediment, and bromophenolic ('iodoform') smell (Steward et al. 1992). The upper 6 to $8 \mathrm{~cm}$ of the burrow is vertical and straight; below this portion the burrow is spiral and often extends laterally or at angles into the deeper sediments. The upper portion of the burrow is occupied by the tail of $N$. lobatus, where the highest concentrations of bromophenols in the polychaete are found (Yoon et al. 1994). N. lobatus produces high levels of 4-bromophenol, 2,4-dibromophenol, and 2,4,6-tribromophenol, with 4-bromophenol being the most abundant compound in the polychaete and in sediments surrounding its burrows (Chen et al. 1991, Steward et al. 1992, Lincoln et al. unpubl. data). Two $N$. lobatus wormbed sites have been used extensively for related research and were described previously (Steward et al. 1992, 1996, Steward \& Lovell 1997). Samples for this study were collected from both sites. The 4 -bromophenol levels in wormbed sediments are high, averaging over $100 \mathrm{ng} \mathrm{g}^{-1}$ sediment (Steward et al. 1992, Steward \& Lovell 1997). In addition, 2,4-dibromophenol and 2, 4,6-tribromophenol are found at $<10 \mathrm{ng} \mathrm{g}^{-1}$ sediment levels in the wormbeds. Other bromophenol producing worms are rare in $N$. lobatus beds and volatile haloaromatic compounds other than bromophenols have not been detected at these sites (Steward \& Lovell 1997). A nearby intertidal sediment site (Bly Creek) that has very low levels of bromophenols (mean 4-bromophenol conc. $=6 \mathrm{ng} \mathrm{g}^{-1}$ sediment, Steward \& Lovell 1997) served as a comparison site for these experiments. No volatile halometabolite producing organisms have been identified at this location, which is similar in elevation, inundation period, sediment characteristics, bacterial numbers per gram (dry weight) of sediment, and rates of 4 -bromophenol respiration and assimilation to the bromophenol containing sites (Steward \& Lovell 1997).

Sampling and sample analysis. Sediment cores for radiotracer studies were collected at low tide on several dates from June of 1993 through June of 1996. Cores were collected using cut-off $10 \mathrm{ml}(1.4 \mathrm{~cm}$ diameter, $6 \mathrm{~cm}$ length) plastic syringes with self-sealing $1 \mathrm{~mm}$ diameter injection ports at $1 \mathrm{~cm}$ vertical intervals. The $6 \mathrm{~cm}$ core length corresponds to the vertical 
(tail occupied) portion of the Notomastus lobatus burrows and prevents sampling of the more varied spiral portion at greater depths. Sets of sediment cores were collected in a randomized block design at both the non-bromophenol containing site and wormbed sites. The presence of $N$. lobatus in the wormbed sites was confirmed by visual observation of burrow openings and excavation of worms at each sampling. Cores from each block sampling were randomly assigned to treatments and analyses (i.e. glucose or acetate injection and substrate assimilation or respiration measurements). Porewater samples for preparation of substrate and 4-bromophenol stock solutions were collected and transported to the lab on ice. The porewater was filter sterilized (0.2 $\mu \mathrm{m}$ pore size) and degassed before use.

Sediment cores for assimilation measurements were injected with 37 to $185 \mathrm{kBq}$ core $\mathrm{e}^{-1}\left(30 \mu \mathrm{l}, 5 \mu \mathrm{l}\right.$ port $^{-1} ; 1.5$ to $5 \mu \mathrm{Ci}$ core ${ }^{-1}$ ) of ${ }^{3} \mathrm{H}$-acetate (specific activity $225 \mathrm{GBq}$ $\mathrm{mmol}^{-1}$ ) or $185 \mathrm{kBq}$ core $^{-1}\left(30 \mu \mathrm{l}, 5 \mu \mathrm{l} \mathrm{port}{ }^{-1} ; 5 \mu \mathrm{Ci}\right.$ core $\mathrm{e}^{-1}$ ) ${ }^{3} \mathrm{H}$-glucose (specific activity 1600 to $1850 \mathrm{GBq}$ $\mathrm{mmol}^{-1}$ ) following established methods (Steward \& Lovell 1992). Sediment cores for respiration measurements were injected with $18.5 \mathrm{kBq} \operatorname{core}^{-1}$ (30 $\mu \mathrm{l}, 5 \mu \mathrm{l}$ port $^{-1} ; 0.5 \mu \mathrm{Ci}$ core ${ }^{-1}$ ) of ${ }^{14} \mathrm{C}$ acetate (uniformly labeled, specific activity $2.1 \mathrm{GBq} \mathrm{mmol}^{-1}$ ) or ${ }^{14} \mathrm{C}$-glucose (uniformly labeled, specific activity $10.9 \mathrm{GBq} \mathrm{mmol}^{-1}$ ) also following established methods (Steward et al. 1992, Steward \& Lovell 1997). Increasing concentrations of 4-bromophenol dissolved in filtered and degassed porewater were also added to sets of sediment cores $\left(10 \mu l\right.$ port $^{-1}, 60 \mu l$ cor $\left.^{-1}\right)$. Added 4-bromophenol resulted in sediment concentrations ranging from about $100 \mathrm{ng} \mathrm{g}^{-1}$ dry weight of sediment (ambient, no 4-bromophenol additon) to about $10.1 \mathrm{\mu g} \mathrm{g}^{-1}$ sediment. Cores were incubated in the dark at in situ temperature. Formalin killed control and autoclaved control cores were injected with radiolabel and 4-bromophenol and incubated and processed in parallel with experimental cores. Appropriate incubation times were determined by performing time course experiments at various times of year. Incubation times of up to $12 \mathrm{~h}$ resulted in linear respiration and assimilation responses (data not shown) and incubation times of 6 or $8 \mathrm{~h}$ were used in these experiments. Cores for respiration rate measurements were processed at the termination of each experiment and cores for assimilation rate measurements were frozen on dry ice and extracted at a later time. Radiolabel recovery methods have been described previously (Steward \& Lovell 1992, 1997. Steward et al. 1992). Respired or assimilated radiolabel was quantified by liquid scintillation counting. Quench correction was by the external standards method.

The SAS System for Windows (version 6.12, SAS Institute, Inc., Cary, NC, USA) was used to perform all statistical analyses. Due to differences among sampling sites, sampling dates, radiolabeled substrates used, and responses measured (i.e. respiration rate or assimilation rate), each data set was considered independent and each was analyzed separately. Regression analysis was used to compare the relationship between increasing 4-bromophenol concentrations and the response measured to an idealized plot having a slope of zero. All data were tested for normality and statistical tests were performed using a significance level of $\alpha=0.05$

\section{RESULTS AND DISCUSSION}

Rates of acetate and glucose assimilation and respiration in intact sediment cores incubated with a broad range of added 4-bromophenol levels were quite similar between the wormbed and non-bromophenol containing sites (Fig. 1). Substrate utilization rates were also consistent across the range of 4 -bromophenol concentrations used for each sampling date. Sediment temperatures on sampling dates ranged from a low of $9^{\circ} \mathrm{C}$ on January 20,1996 , to a high of $31^{\circ} \mathrm{C}$ on June 30 , 1996. Seasonal variations in respiration and assimilation rates were observed, as was the case in previous studies at these sites (Steward et al. 1992, Steward \& Lovell 1997). Regression analysis revealed that data plots from only 2 experiments (June 21, 1993, wormbed acetate assimilation and July 18, 1994, wormbed glucose respiration) had significant slopes, indicating statistically significant responses attributable to added 4-bromophenol (Table 1). In both cases the slopes were positive, indicating possible stimulation, not inhibition, by added 4 -bromophenol. However, little of the variability in these data was explained by these regressions. The other 12 data sets showed no significant effect of added 4-bromophenol on acetate or glucose respiration or assimilation.

Acetate and glucose have been widely used in studies of sediment microbial activity (e.g. Meyer-Reil 1978, Sawyer \& King 1993). Both can serve as carbon/energy sources for many marine microorganisms and acetate is a major substrate for terminal carbon metabolic processes in marine sediments (e.g. Christensen \& Blackburn 1982, Christensen 1984, Shaw \& McIntosh 1990). Consequently, inhibitory effects of 4 -bromophenol on sediment bacterial assemblages should result in inhibition of acetate and/or glucose utilization. Inhibition of sediment microbial metabolism in response to added 4 bromophenol was not observed for either bromophenol containing or non-containing sediments. It is particularly interesting that sediment microflora with no significant prior exposure to biogenic bromophenols were as insensitive to inhibitory effects of 4 -bromophenol as 

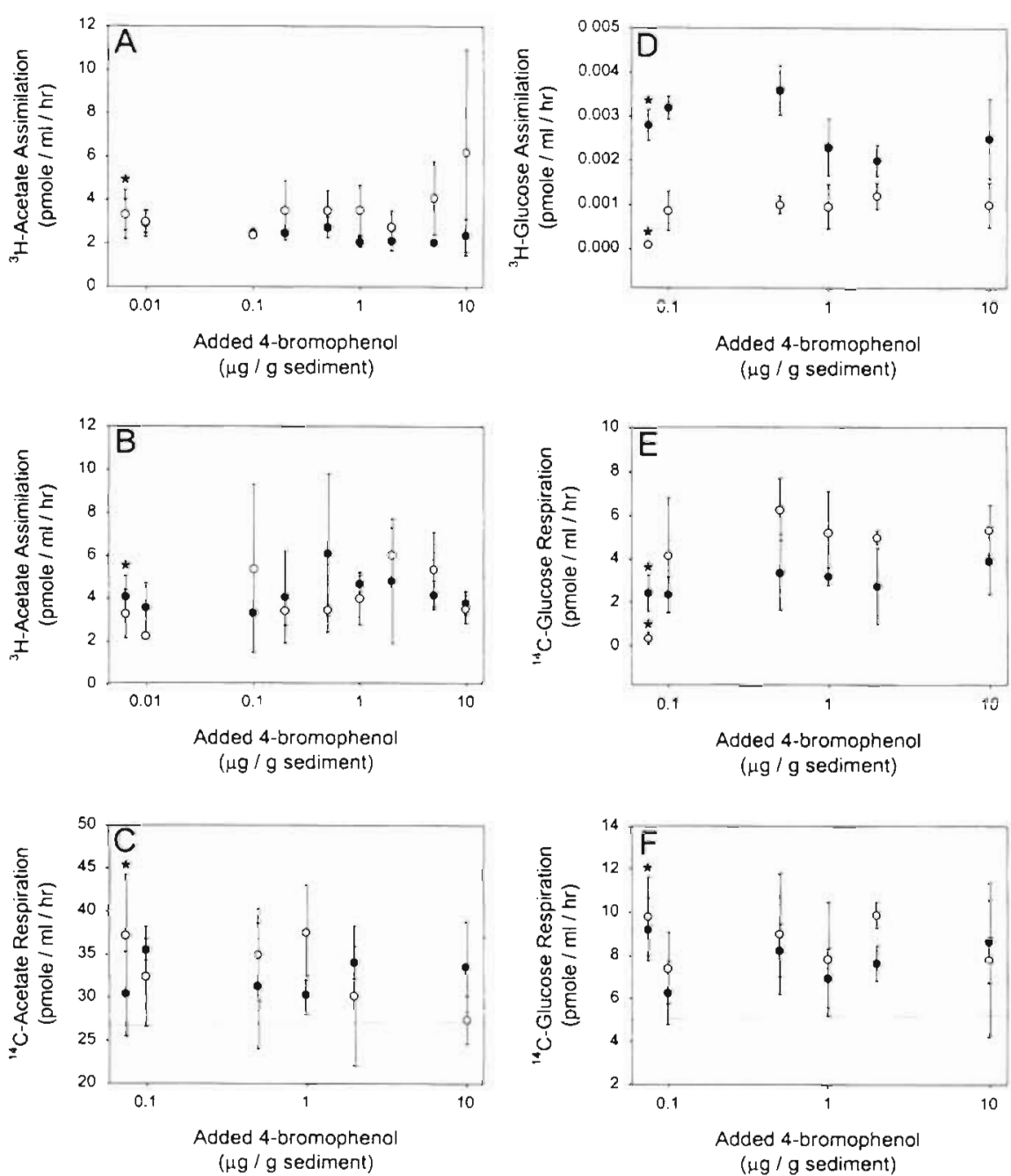

Fig. 1 Microbial responses to added 4-bromophenol in intact sediment cores collected from wormbed (O) and non-wormbed (-) sites. Acetate assimilation dose-responses in cores collected on (A.) June 21, 1993, and (B) January 10, 1994, acetate respiration dose-responses in cores collected on (C) October 8, 1994, glucose assimilation dose responses in cores collected on (D) January 20 . 1996, and glucose respiration doseresponses in cores collected on (E) January 20, 1996, and (F) June 30, 1996, are shown to provide an overview of results from numerous different experiments (see Table 1). Rates are expressed as pmole of substrate respired or assimilated per $\mathrm{ml}$ of sediment per hour of incubation. Added quantities of 4-bromophenol are given in $\mu \mathrm{g}$ per $\mathrm{g}$ (dry weight) of sediment. Values are means $(n=3)$, error bars represent 1 standard deviation. For symbols with no error bars, error bars are smaller than the symbols. Respiration and assimilation rate values for ambient (zero added) 4-bromophenol treatments are included in the plots (off scale) and indicated by asterisks microbial assemblages chronically exposed to this and other bromophenols. Resistance to bromophenol toxicity clearly does not require adaptation of the assemblage to these compounds. This was also the case for 4 bromophenol turnover, which occurred at comparable rates in chronically contaminated and uncontaminated sediments (Steward \& Lovell 1997).

Among the many biogenic brominated aromatic compounds produced by marine infauna, 4-bromophenol was the most useful for this study. This compound is the most abundant bromophenol in Notomastus lobatus sediments and is quite soluble in seawater, making it easy to introduce into sediment cores without disturbing the samples. Giray \& King (1997) reported differential inhibition of nitrification by several bromophenols, with 4-bromophenol and 2,4-dibromophenol the most inhibitory of the compounds tested. They observed strong inhibition of nitrification in slurries incubated with 0.2 to $2.2 \mu^{-1} g^{-1}$ (dry weight of sediment) levels of 4 -bromophenol. These levels are well within the range of added 4-bromophenol concentra- tions we tested. Based on the results of Giray \& King (1997) and previous reports of diverse and thriving microbial assemblages in burrow linings of infaunal species producing various bromophenols (Alongi 1985, Jensen et al. 1992, Steward et al. 1995, 1996), it seems very unlikely that other biogenic bromophenols would have been substantially more inhibitory to undisturbed sediment microbial communities than 4 -bromophenol. In addition, the highest levels of 4 -bromophenol used in these experiments were about $100 \times$ the ambient levels typically found in wormbed sediments and over $10 \times$ the level of total bromophenols in $N$. lobatus burrow linings. At such high doses, any inhibitory effects should have been easily detected.

Degradation of added 4-bromophenol during the incubations cannot account for the absence of inhibitory effects. Rates of 4-bromophenol degradation have been determined in both 4 -bromophenol containing and non-containing sediments from the sites used in this study (Steward \& Lovell 1997) and are too low to significantly decrease the rather high levels of 4 -bro- 
mophenol added in most treatments during the short incubations used. Low level additions (i.e. ambient to $0.1 \mu \mathrm{g} \mathrm{g}^{-1}$ addition) could be affected by degradation, but levels of this compound in wormbed sediments, where 4 -bromophenol degradation certainly occurs, are typically around $0.1 \mu \mathrm{g} \mathrm{g}^{-1}$. This may represent a threshold level below which the compound is not efficiently mobilized or degraded under in situ conditions.

Studies employing intact sediment cores (Steward et al. 1992, Steward \& Lovell 1997, this study) or examining burrow linings that were not homogenized or incubated with a substrate (Alongi 1985, Jensen et al. 1992, Steward et al. 1996) have consistently shown no inhibition of sediment microbiota by infaunal bromometabolites. These results differ from those of King $(1986,1988)$ and Giray \& King (1997), who reported substantial inhibition of sediment slurry aerobic microbial activities by bromometabolites. A number of reasons for this discrepancy can be proposed. (1) Preparation of sediment slurries and long incubations produce profound changes in sediment structure and microbial activities. Temporary stimulation of activity and growth of sediment microbial communities due to disturbance has been well documented (Findlay et al. 1985, 1990). Since highly active, rapidly growing bacteria are typically more susceptible to microbiocides than slow growing organisms, microbial assemblages stimulated in this fashion may be more sensitive to bromophenols than undisturbed assemblages. (2) Slurry preparation may disrupt biofilms and cellular or organic aggregates that may, when intact, shield bacteria from inhibitors. Biofilms are well known to protect organisms residing in them from disinfectants (reviewed in Costerton et al. 1987. Nichols 1991) and the natural sediment matrix and the biofilms lining infaunal burrows (Steward et al. 1996, T. Phillips \& C. R. Lovell unpubl. data) may have similar shielding effects. (3) The methods used here and in similar studies to assay microbial activities in intact sediment cores may be insufficiently sensitive to detect changes in microbial activities which result from either mild, but broad spectrum inhibition, or strong, but narrow spectrum inhibition (Giray \& King 1997). Our experimental designs have consistently targeted microbial activities we consider broadly distributed across a wide range of different microbial populations, such as acetate and glucose turnover by bacteria (Steward et al. 1992, this study) and primary production by benthic microalgae (Stew- ard et al. 1992). We have also targeted processes that can be readily assayed using intact cores and short incubations. It would be very difficult to prove conclusively that very minor inhibitory activity would be detected in these studies, but certainly none has been over the course of many experiments employing undisturbed sediment cores and unincubated burrow lining samples (Alongi 1985, Jensen et al. 1992, Steward et al. 1992, 1996, Steward \& Lovell 1997, this study). It is clear that at least some aerobic microbial populations are susceptible to inhibition by bromophenols which, along with other substituted phenols, are known inhibitors of higher organism respiratory metabolism (Stockdale \& Selwyn 1971a,b). However, it is not at all clear that sediment microbial assemblages are as vulnerable to bromophenols in nature as they are in laboratory studies. Based on present evidence, we do not consider biogenic bromophenols to have any significant inhibitory effect on sediment microflora in situ. Other ecological roles of bromophenols, including their allelopathic effects may be much more significant.

Acknowledgements. We thank Sarah A. Woodin and David E. Lincoln for their expertise on infaunal worms and halophenol quantification, respectively, George Matsui for technical assistance, and Sarah Woodin and Holmes Finch for advice on statistical analyses. This research was supported by NSF 
grant OCE-9201857 and EPA grant R82-4776-010 to S. A. Woodin, D. E. Lincoln, and C.R.L. A preliminary account of this research was presented at the 95th General Meeting of the American Society for Microbiology, Washington, DC, USA. This is contribution No. 1167 of the Belle W. Baruch Institute for Marine Biology and Coastal Research.

\section{LITERATURE CITED}

Alongi DM (1985) Microbes, meiofauna, and bacterial productivity in tubes constructed by the polychaete Capitella Capitata. Mar Ecol Prog Ser 23:207-208

Ashworth RB, Cormier MJ (1967) Isolation of 2,6-dibromophenol from the marine hemichordate, Balanoglossus biminiensis. Science 155:1558-1559

Chen YP, Lincoln DE, Woodin SA, Lovell CR (1991) Purification and properties of a unique flavin-containing chloroperoxidase from the capitellid polychaete Notomastus lobatus. J Biol Chem 266:23909-23915

Christensen D (1984) Determination of substrates oxidized by sulfate reduction in intact cores of marine sediments. Limnol Oceanogr 29:189-192

Christensen D, Blackburn TH (1982) Turnover of ${ }^{14} \mathrm{C}$-labeled acetate in marine sediments. Mar Biol 71:113-119

Costerton JW, Cheng KJ, Geesey GG, Ladd TI, Nickel JC, Dasgupta M, Marrie TJ (1987) Bacterial biofilms in nature and disease. Annu Rev Microbiol 41:435-464

Dame R, Chrzanowski T, Bildstein K, Kjerfve B, McKellar $H$, Nelson D, Spurrier J, Stancyk S, Stevenson H, Vernberg J, Zingmark R (1986) The outwelling hypothesis and North Inlet, South Carolina. Mar Ecol Prog Ser 33:217-229

Fielman KT, Targett NM (1995) Variation of 2,3,4-tribromopyrrole and its sodium sulfamate salt in the hemichordate Saccoglossus kowalevskii. Mar Ecol Prog Ser 116: $125-136$

Findlay RH, Pollard PC, Moriarty DJW, White DC (1985) Quantitative determination of microbial activity and community nutritional status in estuarine sediments: evidence for a disturbance artifact. Can J Microbiol 31:493-498

Findlay RH, Trexler MB, Guckert JB, White DC (1990) Laboratory study of disturbance in marine sediments: response of a microbial community. Mar Ecol Prog Ser 62:121-133

Giray C, King GM (1997) Effect of naturally occurring bromophenols on sulfate reduction and ammonia oxidation in intertidal sediments. Aquat Microb Ecol 13:295-301

Goerke H, Weber K (1991) Bromophenols in Lanice conchilega (Polychaeta, Terebellidae): the influence of sex, weight and season. Bull Mar Sci 48:517-523

Jensen P, Emrich R, Weber K (1992) Brominated metabolites and reduced numbers of meiofauna organisms in the burrow wall lining of the deep-sea enteropneust Stereobalanus canadensis. Deep-Sea Res 39:1247-1253

King GM (1986) Inhibition of microbial activity in marine sediments by a bromophenol from a hemichordate. Nature 323:257-259

King GM (1988) Dehalogenation in marine sediments containing natural sources of halophenols. Appl Environ Microbiol 54:3079-3085

Editorial responsibility: Otto Kinne (Editor),

Oldendorf/Luhe, Germany
Meyer-Reil LA (1978) Uptake of glucose by bacteria in the sediment. Mar Biol 44:293-298

Nichols WW (1991) Biofilms, antibiotics and penetration. Rev Med Microbiol 2:177-181

Pawlik JR (1993) Marine invertebrate chemical defenses Chem Rev 93:1911-1922

Pinckney J, Zingmark R (1993) Biomass and production of benthic microalgal communities in five typical estuarine habitats. Estuaries 16:887-897

Prezant YM, Gruber G, Counts CL (1981) Predator repellents of benthic macro-invertebrates. Am Zool 21:1022

Sawyer TE, King GM (1993) Glucose uptake and end product formation in an intertidal marine sediment. Appl Environ Microbiol 59:120-128

Shaw DG, McIntosh DJ (1990) Acetate in recent anoxic sediments: direct and indirect measurements of concentration and turnover rates. Estuar Coast Shelf Sci 31:775-788

Sheikh YM, Djerassi C (1975) 2,6-dibromophenol and 2,4,6tribromophenol-antiseptic secondary metabolites of Phoronopsis viridis. Experientia 31:265-392

Steward CC, Lovell CR (1992) Improved method for recovery and quantitation of assimilated radiolabel from marine sediment bacteria. J Microbiol Methods 16:221-230

Steward CC, Lovell CR (1997) Respiration and assimilation of 4-bromophenol by estuarine sediment bacteria. Microb Ecol 33:198-205

Steward CC, Pinckney J, Piceno Y, Lovell CR (1992) Bacterial numbers and activity, microalgal biomass and productivity and meiofaunal distribution in sediments naturally contaminated with biogenic bromophenols. Mar Ecol Prog Ser 90:61-72

Steward CC, Dixon TC, Chen YP, Lovell CR (1995) Enrichment and isolation of a reductively debrominating bacterium from the burrow of a bromometabolite producing marine hemichordate. Can J Microbiol 41:637-642

Steward CC, Nold SC, Ringelberg DB, White DC, Lovell CR (1996) Microbial biomass and community structures in the burrows of bromophenol producing and non-producing marine worms and surrounding sediments. Mar Ecol Prog Ser 133:149-165

Stockdale M. Selwyn MJ (1971a) Influence of ring substituents on the action of phenols on some dehydrogenases, phosphokinases and the soluble ATPase from mitochondria. Eur J Biochem 21:416-423

Stockdale M, Selwyn MJ (1971b) Effects of ring substituents on the activity of phenols as inhibitors and uncouplers of mitochondrial respiration. Eur J Biochem 21:565-574

Woodin SA (1991) Recruitment of infauna: positive or negative cues? Am Zool 31:797-807

Woodin SA, Walla MD, Lincoln DE (1987) Occurrence of brominated compounds in soft-bottom benthic organisms. J Exp Mar Biol Ecol 107:209-217

Woodin SA, Marinelli R, Lincoln DE (1993) Allelochemical inhibition of recruitment in a sedimentary assemblage. J Chem Ecol 19:517-530

Yoon KS, Chen XP, Lincoln DE, Lovell CR, Knapp LW, Woodin SA (1994) Localization of the chloroperoxidase of the capitellid polychaete Notomastus lobatus. Biol Bull 187 : 215-222

Submitted: September 17, 1998; Accepted: November 18, 1998 Proofs received from author(s): March 23, 1999 